\title{
A ILUSÃO DE BEM VIVER E A ARTE DE BEM MORRER NO IL GATTOPARDO DE T. LAMPEDUSA
}

\author{
Filipa Marisa Gonçalves Medeiros Araújo* \\ medeiros.filipa@gmail.com
}

\begin{abstract}
RESUMO: A leitura da obra-prima de Lampedusa tende a seguir uma orientação de leitura condicionada pelas coordenadas espácio-temporais do autor ou das personagens. Importa, no entanto, salientar que a complexa tessitura literária do romance histórico permite estabelecer perspetivas intertextuais fora desse circuito referencial mais imediato. Tomando como fio condutor o corteggiamento della morte, que desempenha um papel estruturante no romance, é possível identificar vestígios de uma herança deixada pelos esquemas mentais da dialética barroca. A presença do motivo tanatológico na obra não se resume a uma isotopia temática, assume-se, antes, como um traço determinante na caracterização do protagonista e na própria conceção da narrativa, pelo que se propõe uma análise textual à luz dos preceitos estipulados pelas Artes bene moriendi seiscentistas. O cotejo com o manual ascético de Bellarmino evidencia, assim, os pontos de convergência entre dois textos distanciados pelo tempo e pelo género, mas aproximados pela perspetiva tanatológica que refletem.
\end{abstract}

PALAVRAS-CHAVE: Romance histórico: Morte; Ars moriendi.

\section{A SOMBRA DA MORTE NO REFLEXO DA VIDA}

Na Primavera de 1958, volvido um ano sobre a morte do Príncipe de Lampedusa, Giorgio Bassani descobriu o manuscrito de Il Gattopardo e reconheceu, de imediato, naquelas páginas um texto ainda mais interessante do que a versão dactilografada que já tinha lido. Procurou, então, dá-lo a conhecer ao mundo, consciente de que aquela obra se tornaria um dos grandes êxitos da Literatura Universal do século XX. A ideia inicial de compor um romance histórico, manifestada vinte e cinco

${ }^{*}$ Mestre e Doutoranda. Faculdade de Letras da Universidade de Coimbra / Centro Interuniversitário de Estudos Camonianos. 
anos antes, preconizava um enredo contemporâneo do desembarque de Garibaldi em Marsala, e desenvolvido em torno da figura do bisavô paterno, Giulio di Lampedusa, que emprestou a Fabrizio o gosto pela Astronomia. No entanto, a conceção do desígnio foi sendo adiada até que, talvez adivinhando o rápido esgotamento do tempo disponível, Lampedusa começou por esboçar as primeiras páginas e logo fez jorrar o estilo num fluir contínuo, que corria com a força da sua erudição, à velocidade da sua inteligência perspicaz. A libertação dessa torrente contida, como nota Bassani (2005), coloriu as palavras de encantadora expressividade, a que não faltou o tom melodioso de quem contorna obstáculos com subtil humorismo. Muito se tem escrito sobre o poliédrico segredo do extraordinário sucesso deste romance, salientando os aspetos histórico-sociológicos e estilísticos ${ }^{1}$. Afigura-se-nos, no entanto, particularmente relevante sublinhar o contributo da temática subjacente, porque lhe confere a dimensão humana e atemporal que carateriza uma obra-prima universal.

Il Gattopardo ultrapassou as limitações de uma obra situada no tempo e cedo conquistou a adesão dos críticos, mas demorou a convencer o grande público, naturalmente esquivo a textos que exigem uma leitura mais reflexiva. Lampedusa exige do seu interlocutor uma postura dinâmica, inquieta e consciente da natureza do homo sapiens, quer na sua condição particular, quer na sua vivência coletiva. O Príncipe de Salina representa simultânea e cumulativamente o indivíduo, a família e a sociedade, ou pelo menos, a sua classe social. Não nos surpreende, por isso, que o espectro da morte perpasse todo o romance, desde a oração inicial - "Nunc et in hora mortis nostrae. Amen" - até ao capítulo final, onde se torna visível a aniquilação total, a que corresponde o fim da vida. Esta omnipresença mórbida foi notada por vários autores ${ }^{2}$ e Squarotti (1961, p. 281) conclui: "Una grande tragedia funebre, una contemplazione della morte costituisce il tema supremo del Gattopardo, la ragione ultima della sua poesia”.

Também Luigi Russo (1960, p. 513) elegeu o "corteggiamento della morte" como ponto fulcral da obra, visto que não se resume a uma isotopia temática, configura-se antes como uma sombra omnipresente no próprio modus vivendi do tio de Tancredi. A sua existência vai percorrendo o sinuoso caminho de quem lamenta o presente em função do passado, de quem reage à inovação em nome da tradição, de quem encara a vida com os olhos postos na morte. Daí que toda a ambiência do romance se paute pela resistência à mudança e pelo apego a uma realidade matizada pelos contrastes típicos da mentalidade barroca, pois esta prevaleceu na terra natal de Lampedusa muito para além do século XVIII. Tendo em conta essa mundividência fortemente determinada pela doutrina religiosa, não admira que o Príncipe de Salina quisesse manter uma obstinada fidelidade a um código de valores e de comportamentos já obsoleto, segundo o qual o homem devia viver em função da sua absolvição no juízo final. Procurar-se-á demonstrar, por conseguinte, que essa postura vai ao 
encontro da visão teleológica que ditava os preceitos das Artes moriendi, muito em voga até aos finais de Setecentos. Importa traçar, neste sentido, algumas linhas de orientação para uma leitura cotejada do romance com o manual edificante de Bellarmino, de modo a evidenciar as sombras da morte projetadas no reflexo da vida que Lampedusa pretendeu retratar a contraluz.

\section{UMA VIVÊNCIA DE CONTRASTES, SOB O MANTO DIÁFANO DA IRONIA}

Contornando a polémica relativa à classificação genológica e ao enquadramento da obra no contexto da Literatura Italiana do novecento, convém, todavia, recordar que o tema da contemplatio mortis é um dos aspetos que o romance histórico de Lampedusa partilha com o movimento decadentista. Esta tendência artística e literária espalhou-se pela Europa a partir dos finais do século XIX até aos inícios do século passado, no seguimento da crise do pensamento positivista e do descrédito do cientismo. Propunha-se, então, uma reação irracionalista que valorizasse a equação do indivíduo como ser complexo, à luz das teorias psicanalíticas de Freud, que vieram corroborar uma atitude cética perante a existência humana. No plano literário, privilegiou-se uma nova sensibilidade estética, para exprimir os matizes do mal du siècle, com todos os traços de dor que compõem uma paleta de sensações impressionistas (Maeterlinck, 1917). A 26 de Maio de 1883, Paul Verlaine publicou, no periódico "O gato negro", o soneto intitulado Langueur, que viria a marcar o movimento com o estigma indelével do pessimismo fatalista. Esta postura afeta D. Fabrizio, quando se coloca na triste posição do espetador que assiste à ruína do seu império e do seu mundo, como se adotasse a atitude indolente de quem se estende ao sol com languidez, assumindo o cansaço como um estado permanente, à espera da extinção dos seus dias com o desencanto de se saber condenado à aniquilação, sob o inevitável signo da esterilidade.

O próprio Príncipe de Lampedusa, descrito como "un signore alto, corpulento, taciturno; pallido, in volto, del pallore grigiastro dei meridionali di pelle scura. (...) silenzioso sempre, sempre con la medesima piega amara delle labra." (BASSANI, 2005, p. 8), personifica essa imagem cinzenta de quem vive com a consciência de ter chegado ao fim de um ciclo civilizacional. A bélica ambição do imperialismo, o fracasso do ideal positivista e as desigualdades da sociedade industrializada obrigaram o homem a enfrentar uma realidade cada vez mais distante dos ideais da Revolução Francesa, pois a poderosa burguesia depressa esqueceu os princípios fraternos em prol dos interesses próprios. O intelectual tornou-se, então, o porta-voz da consciência social, denunciando o abismo dos 
novos tempos e a impossibilidade do retorno à época dourada. A mesma desconfiança face ao advento de uma nova era norteia a resposta do último dos Leopardos à requesta do Estado unificado, recusando-se a participar na ruína universal. O protagonista revela, pois, alguns traços comuns ao herói decadente, que prefere ensimesmar-se no seu mundo interior, ou então refugiar-se na procura de ambientes exóticos que encontram uma variante nas observações do universo longínquo metodicamente realizadas. D. Fabrizio parece, de facto, ter herdado da visão decadentista de Pirandello a consciência da crise e a lucidez do discurso crítico, em que manifesta os rasgos de superioridade da sua elegância aristocrata. No alto de uma torre esclarecida, o Príncipe assume o papel do poeta veggente, o único que, na sua solidão, tem clarividência para vislumbrar um microcosmo interior, mergulhando na esfera do seu íntimo para meditar sobre as sensações do seu "eu" misterioso, do seu lado lunar, que muitas vezes se perde no infindável labirinto das correntes estéticas finisseculares ${ }^{3}$.

O motivo decadente do presságio mórbido atravessa, pois, todo o romance e cola-se à caraterização da personagem principal, refletindo simultaneamente o topos clássico do inexorável fluir do tempo, que inspira o homem desde o canto mais arcaico da poesia grega, na poesia sentimental de Mimnermo. O elegíaco de Cólofon (séc. VII- VI a. C.) comparava a vida do homem às folhas das árvores, para concluir que "Pouco dura o fruto da juventude/ o tempo de o Sol derramar a sua luz sobre a terra./ E depois, logo que chega o fim da estação/ Melhor é morrer logo do que viver" porque "Não há homem a quem Zeus não dê muitos infortúnios." (Rocha pereira, 1998, p. 112).

Reconhecendo o fim da estação mais vigorosa, pressentido o declínio da casa e a ruína da família, e lamentando não ter um descendente com a sua garra felina, o pai de Concetta começou, com efeito, a desejar a morte, experimentando o mesmo sentimento que inebriou o compositor da Grécia Antiga, face à inevitável conceção dolorosa da vida humana, sujeita à implacável vontade divina. Recorremos, pois, a este testemunho longínquo para reforçar a ideia de que a interpretação da morte como fuga a uma vida necessariamente precária perde-se no tempo e prende-se com os naturais mecanismos de evasão que convidam o homem a ludibriar a consciência da sua finitude.

Quando, já no leito de morte, o Príncipe recorda o afastamento do filho Giovanni, conclui que esse corte com as raízes pátrias tinha sido, afinal, uma forma de aniquilação da sua existência, permitindo o recomeço num outro lugar, uma nova oportunidade de construir um percurso biográfico diferente. Na sua essência, aquele era o único que se assemelhava ao pai, porque seguira o seu instinto de fuga: "Anche lui aveva «corteggiato la morte», anzi con l'abbandono di tutto aveva organizzato per sé quel tanto di morte che è possibile metter su continuando a vivere" (p. 206). Este 
comentário sugere uma reflexão curiosa sobre a tensão dicotómica que estimula a conduta das personagens e reveste a própria ambiência do romance. Emana de Il Gattopardo a nítida perceção de que o percurso do homem é sempre traçado em função de dois vetores contrários: o desejo de aproveitar a vida e a certeza da morte, pelo que cada uma das personagens vai desenvolvendo estratégias que visam atenuar o inevitável avanço para o fim. Giovanni e Fabrizio são talvez os únicos a contrariar essa força centrífuga com aparente sucesso, através da morte. O primeiro procura reescrever a sua história pessoal apagando as coordenadas espácio-temporais que apadrinharam o seu nascimento, num gesto que lembra a demanda existencialista de Il fu Mathia Pascal. O Príncipe, porém, não se contenta com um desaparecimento dissimulado, nem o seu vasto saber de experiência feito o permitiria, daí que comece a perspetivar o momento do derradeiro suspiro como uma forma de libertação, a única possível, para apaziguar o seu doloroso caminho num mundo em decadência.

De facto, essa consciência mórbida confere-lhe a lucidez particular que possibilita a interpretação dos inúmeros contrastes que modelam a existência humana, no geral, e o particular comportamento dos contemporâneos no teatro da realidade coeva. No entanto, é sobretudo ao narrador que compete exprimir essa observação esclarecida, adotando a ótica do protagonista, pelo que os seus discursos se confundem numa opinião partilhada. A mundivisão do governante de Salina predomina em toda a obra, ainda que o relator dos factos recorra a uma estratégia de falso distanciamento através da ironia, imprimindo ao discurso um tom ensaístico, de modo a manter "uno schermo di ragionamento, di spiegazione, di sistemazione critica fra la parola e la realtà" (SQUAROTTI, 1961, p. 279).

$\mathrm{Na}$ verdade, o responsável pela narrativa soube sugerir com mestria esse jogo de contrastes que se torna visível, tanto na caracterização das figuras, como na descrição dos ambientes. Reconhece-se, antes de mais, uma certa duplicidade de planos entre realidade e ficção, enfatizada pela ironia lúcida do narrador, como se fosse uma lente através da qual se propõe uma leitura simbólica dos acontecimentos, sublinhando o carácter repetitivo dos erros humanos no devir cíclico da História. O leitor reconhece no tom irónico do discurso a mesma amargura desenganada do representante da velha aristocracia que, no momento de maior desespero, dá voz ao sofrimento de toda a nação siciliana. Enquanto baluarte do antigo regime, já démodé, o Príncipe revela um entendimento apurado das incertezas implicadas na mudança de regime, uma situação que a História apresenta sempre sem certezas, mas com expectativas muitas vezes defraudadas. Por isso, as reflexões de D. Fabrizio comportam, ou pelo menos evocam, a desilusão de quem assistiu ao derrubar do seu palácio durante os bombardeamentos da Segunda Guerra, causando uma ferida ainda latente e o travo 
amargo de quem assiste ao cego repisar dos erros, na vã esperança de mudar o mundo.

Entre a realidade e a ficção, o manto diáfano da ironia vai alertando o leitor para alguns aspetos que maculam a tradicional visão eufórica do Risorgimento. No domínio social, denuncia-se a ludibriada democracia do plebiscito, a elegância já decadente dos palácios aristocratas, a dissolução das propriedades senhoriais retratadas em grande estilo nos quadros de parede e o requinte ilusório dos grandes bailes, onde, apesar de a dança incutir nos corpos a sensação frenética de apogeu, prevalecem os interlúdios de reflexão sobre a morte, pressagiando a derrocada iminente. Além disso, a oposição contrastiva é também refletida no próprio espaço, nomeadamente no apolíneo jardim, cuja descrição sensacionista coloca paradoxalmente em relevo as marcas degenerativas sopradas pelo perfume da rosa Paul Neyron e pelo cadavérico odor do soldado morto debaixo do limoeiro. Mesmo nesse lugar idílio, a morte faz sentir a sua presença, não menos expressiva na imagem dos inúmeros aposentos do palácio, entregues ao pó do esquecimento, ainda que o amor de Tancredi e Angelica os procure reanimar, levando um pouco de energia àquela morada dos mortos, votada ao vazio. $\mathrm{O}$ mesmo vazio que cobre a paisagem deserta da Sicília, que aceita a sua aridez como fator de submissão, ao mesmo tempo que reivindica a supremacia reservada aos deuses, como se depreende do discurso ao enviado de Turim (p. 153).

Ora, esta apurada perceção dualista aplica-se também ao domínio privado das personagens, que não escondem a sua composição híbrida, entre o apolíneo e o demoníaco. Os pobres habitantes de Donnafugata, de Palermo e de San Cono são figurantes da miséria que facilmente vendem a sua fidelidade; Tumeo, veículo da vox populi, sustenta uma patética lealdade aos reis borbónicos, cuja motivação parece prender-se mais com a inveja pessoal do que com a preocupação do bem comum; o piemontês Chevalley, apesar de demonstrar uma ingenuidade honesta, evidencia um código ideológico votado ao fracasso; Calogero Sedara sugere, em traços quase caricaturais, a incompatibilidade entre o sucesso económico e a integridade moral formada pela educação e pela cultura intelectual; Angélica, com o seu extraordinário poder sedutor, personifica a oposição entre a beleza aparente e a nobreza de carácter; Stella e Concetta, por sua vez, são mulheres convencionalmente requintadas e submissas, a quem falta, porém, a essência feminina que as torne desejáveis; o Padre Pirrone, embora seja um representante da Igreja, envolve-se inevitavelmente com os problemas mundanos e preocupa-se demasiado com a confortável posição da sua classe e com o apaziguamento das querelas familiares, onde prevalece o desejo de vingança e a ganância; Tancredi, por fim, facilmente sacrifica a bandeira da ideologia libertadora quando lhe acenam com as aliciantes vantagens de uma carreira diplomática.

Acrescente-se a este rol de personagens criadas com o intuito de representar determinados Hist. R., Goiânia, v. 18, n. 2, p. 337-371, jul. / dez. 2013 
agentes sociais de especial relevo na época (o aristocrata, o burguês, o rebelde), um importante trio de personalidades históricas, também elas submetidas a uma análise parcialmente disfórica, ou pelo menos dissonante. O dialeto regional do Rei Fernando, a rápida transformação do libertador Garibaldi em inimigo e a fanfarronice do coronel Pallavicino indiciam a volubilidade da sua existência, sobretudo quando observada em confronto com a universal lei da obliteração. Todas estas

figuras recebem do Príncipe de Salina um olhar altivo. Abnegado dos problemas do seu povo, indiferente aos sentimentalismos do padre Pirrone, insensível aos histerismos da mulher, inflexível perante o sofrimento da filha, cético relativamente ao amor de Tancredi e Angélica, tudo lhe parece insignificante perante a inefável certeza da morte. Ainda assim, Squarotti (1961, p. 282) interpreta a atenção momentânea concedida por D. Fabrizio aos que o rodeia como um sinal de compaixão, embora os acontecimentos lhe mereçam um juízo impiedoso.

Evidencia-se, portanto, no romance, uma notável aptidão para percecionar a complexidade do Homem, em todas as suas dimensões, exprimindo as suas limitações e capacidades, num jogo de contrastes que o narrador exprime como quem antevê o resultado final através do manto diáfano da ironia.

\section{O ÚLTIMO BALUARTE DA MUNDIVIDÊNCIA BARROCA}

Posta em relevo a habilidade técnica de Lampedusa para explorar a expressividade dos contrastes, cumpre salientar os pontos de contacto entre esta estratégia literária e as estruturas mentais de oposição típicas da mentalidade barroca, porque as afinidades ganham maior significado se tivermos em conta que a Sicília de Lampedusa, e ainda mais a de D. Fabrizio, preservava ainda muitos traços dessa mundividência.

É o próprio protagonista quem realça a forte componente psicológica da realidade temporal na ilha. Quando recebe Chevalley no estúdio decorado com uma simbólica constelação de retratos, entre os quais o do patriarca ocupa sintomaticamente o lugar de estrela polar, D. Fabrizio recupera, por breves momentos, a postura do jovem emoldurado que enverga o garboso uniforme da Guarda Real. É precisamente nessa qualidade de servidor da dinastia borbónica que o Príncipe de Salina responde ao embaixador do Reino sediado em Turim, começando por explicar as origens e as razões do modus vivendi siciliano. Recorda, então, a ocupação bizantina, a invasão berbere e o domínio espanhol, para salientar as consequências do estatuto subalterno de colónia, prolongado durante séculos. Lembra 
ainda que o seu povo estava habituado a obedecer e que se sentia velho de mais para correr atrás das maravilhas do mundo moderno, porque não passava de uma velha carcaça incapaz de assimilar as novidades apresentadas na Exposição Universal de Londres. Por fim, o aristocrata confessa-se entediado diante da inovação e declara a sua resistência a tudo o que implique o tremendo incómodo de sair da cama, debaixo da qual afirma manter o antiquado bacio (p. 148). Esta imagem caricatural enfatiza o cansaço extremo que teria levado os sicilianos, exauridos pelos opressores e pelo rigor do próprio clima, a desenvolver um carácter fortemente "condizionato da fatalità esteriori oltre che da una terrificante insularità d' animo" (p. 151).

Ora, a tendência para o isolamento explica-se por fatores histórico-sociológicos, como bem sugere o clarividente Lampedusa, perfeitamente consciente de que a integração no Reino Unificado representava o fim de uma autonomia preservada ao longo de séculos, apesar da ocupação estrangeira. A defesa dessa mesma independência imprimiu na cultura siciliana profundas marcas distintivas, que eram sentidas pelo próprio povo, orgulhoso da sua identidade isolada, tal como revela o discurso do Príncipe, a propósito das manifestações de indolência e de imobilidade típicas dos seus conterrâneos. Esse traço idiossincrático definido como " desiderio di morte; desiderio di immobilità voluttuosa, cioè ancora di morte" (p. 149), ou seja, uma tendência natural para a apatia impassível revela, pois, uma forte resistência à integração num Estado novo, que ameaçava diluir a ancestral origem da cultura siciliana, cuja pretensão de ascendência divina era entendida como garantia de independência. Daí que o governante de Salina mantivesse a sua ligação à "velha classe", se não pelo afeto, pelo menos pela decência, declarando-se livre de qualquer ilusão e incapaz de participar na construção de uma nova Sicília, como pretendia Chevalley (p. 151).

A história de submissão ensinara o povo a obedecer sem revoltas, de modo a preservar incólume a sua essência, intocada pela mudança de regime. Assim se entende que as manifestações artísticas e intelectuais apresentassem um atraso secular, vigorando ainda a mentalidade barroca, marcada pela religiosidade exuberante, pela estética sensorial e pela coincidentia oppositorum. A atração dos opostos torna-se, aliás, um dos mecanismos estruturais na composição do romance e na própria vivência das personagens. Fabrizio personifica o paradoxo de uma província que quer manter a autonomia apesar da sua condição subserviente e descreve a singularidade de um espaço que pretende resistir à ditadura cronológica.

Esta atitude de conformada resiliência faz eco da dicotomia basilar da obra: a eterna tensão entre vida e morte, que coloca o homem em permanente confronto com as suas aspirações/limitações, ao mesmo tempo que desafia a volúvel fronteira entre privado e público. O enamoramento tanatófilo torna-se, por isso, uma força condutora da ação que se desenvolve num 
ambiente ideológico marcado pela sensibilidade barroca, cuja mundividência fortemente ritualizada persistiu na ilha até aos finais do século XIX. Foi então que a unificação política feriu de morte o conservadorismo aristocrático e rompeu as ancestrais manifestações de religiosidade sicilianas, deitando por terra a realidade que ruiu com a queda do último leopardo.

\section{O RITUAL DA MORTE NO RITMO DA VIDA}

Ao considerarmos a isotopia da morte no romance de Lampedusa, levanta-se uma questão inevitável: sendo o Príncipe de Salina, pelo menos aparentemente, um fervoroso adepto da religião cristã, por que razão espera a despedida da vida como o fim de tudo? A crença na imortalidade da alma, já assumida, ou pelo menos pressuposta, pelo culto religioso das civilizações mais antigas, ofereceu desde sempre um lenitivo para a angústia do Homem, perante a dolorosa consciência do seu termo. A doutrina católica, por sua vez, veio acentuar a esperança na redenção post mortem, criando um caminho escatológico para transformar o percurso terreno de provação por entre um vale de lágrimas numa peregrinação de acesso à vida eterna.

De facto, o exemplo de Cristo e a sua mensagem de ressurreição converteu esta passagem pela Terra numa experiência propedêutica que antecede a entrada na verdadeira dimensão da existência. No entanto, importa recordar que esse princípio doutrinal se refletiu de forma diferenciada, de acordo com a mentalidade e as vicissitudes das épocas. A Idade Média, sucessivamente flagelada pela trilogia mortífera (fome, peste e guerra), revestiu naturalmente a morte física de traços aterradores, desenhando um cenário verdadeiramente macabro. Com a conquista de uma vivência mais segura e mais duradoura, o homem renascentista foi alterando essa imagem, através de uma forte aposta na literatura de edificação, que ganhou especial relevo no seio da propaganda reformista e contrarreformista ${ }^{4}$.

No século da grande Reforma Católica, verificou-se, com efeito, uma extraordinária divulgação dos manuais de preparação para a derradeira viagem, comprovando que a sua presença extravasou livremente os limites das bibliotecas conventuais e eclesiásticas, bem como os acervos pessoais dos nobres. No entanto, é preciso notar uma alteração significativa, face à tradição medieval. Os compêndios mais antigos seguiam de perto o ritual da extrema-unção, ministrado pelo padre já na iminência do derradeiro suspiro, indicando as orações e as formalidades a cumprir. O objetivo primordial das artes moriendi renascentistas, por sua vez, não será o de salvar o moribundo, 
in articulo mortis, mas o de ensinar os vivos a preparar antecipadamente a viagem, através de uma prática continuada. Um dos pioneiros desta didatologia moralizadora foi Santo Inácio de Loyola que apresentou, nos Exercícios Espirituais (1548), algumas técnicas de meditação metafísica para exercitar aturadamente, de modo a não deixar para o último suspiro todo o esforço de redenção, construindo a cada momento a garantia de eternidade celeste, com o espírito previdente das dez virgens da parábola bíblica (Mt. 25. 1.13).

De facto, a Igreja da Contra-Reforma procurou aliviar o cenário macabro do arrependimento in extremis, muitas vezes conquistado através de preciosas indulgências, apostando numa despedida mais discreta, que reservasse as últimas forças do moribundo para o ritual mais essencial: o conforto da confissão e o encontro com o viático, como aconselhava Erasmo. Neste sentido, os livros da boa morte pregavam, tal como os sermões, as normas de comportamento piedoso que ofereciam ao homem a possibilidade de garantir a recompensa de toda uma vida pautada pelos rigores ascéticos da meditação e da penitência, o que denota também uma evolução significativa na própria visão teológica sobre a religiosidade individual. O homem, enquanto agente construtor do seu percurso particular, torna-se responsável pelos seus atos e pela opção de seguir ou ignorar os conselhos divinos, consciente de que será submetido a um julgamento privado.

A formação catequética invadiu, assim, a esfera doméstica, pelo que as artes moriendi conheceram uma extraordinária divulgação, impulsionada pelas diretivas do Concílio de Constança (1414-18), onde Jean Gerson, chanceler da Universidade de Paris, promoveu a elaboração de um guia espiritual, cujo protótipo depressa se espalhou pelas redes Dominicanas e Franciscanas de toda a Europa. As primeiras versões, mais longas, depressa deram lugar a edições simplificadas e enriquecidas com gravuras moralizantes, de modo a reconstituir com relativa originalidade artística diferentes momentos da indesejável chegada da morte, numa disposição sequencial. Na senda do Concílio de Trento, os Católicos imprimiram novo fôlego aos tratados de orientação espiritual, dando origem a um multifacetado fenómeno de evangelização, que explorou com sucesso as potencialidades pedagógicas da literatura emblemática. Obras como os Via vitae aeternae iconibus (1620) de Sucquet e os Pia Desideria Emblematis Elegiis et affectibus (1624) de Herman Hugo ofereciam versões ilustradas do percurso igualmente traçado pelas manuais da boa morte contemporâneos. Bellarmino ${ }^{5}$, o cardeal italiano que se tornou patrono dos catequistas em reconhecimento dos seus trabalhos didático-morais, publicou o De Ascensione mentis in Deum em 1615 e reuniu, no De arte bene moriendi (1619), os preceitos de vida honesta e os procedimentos rituais indispensáveis para encontrar a morte sem medo. 
Este manual, dividido em duas partes, começa por fornecer orientações essenciais para uma conduta biográfica de acordo com as virtudes cristãs, respeitando diariamente os sacramentos instituídos e o dever de oração. O segundo livro, por sua vez, concentra-se no momento de aproximação da morte, recomendando a meditação com vista à remissão dos pecados e a necessidade de administrar a extrema-unção, para que o moribundo possa escapar às tentações que o perseguem até ao embarque final. Bellarmino acredita que só uma preparação continuada podia ludibriar o fantasma da morte súbita que muitas vezes surpreende o homem, negando-lhe qualquer hipótese de remir as suas faltas, e sem conceder tempo para apelar à rápida intervenção do cura. Com a intenção expressa de mudar os comportamentos e as mentalidades, o cardeal censura todos os que se preocupam demasiado com os afazeres do quotidiano, em vez de preparar a eternidade. Note-se, porém, que o seu discurso não adota um tom alarmista, antes pelo contrário, recorre a uma linguagem suave e bem estruturada, como nota o tradutor John Dalton (1847, p. IV). Esta perspetiva confiante comprova a já aludida mudança de mentalidade face às artes moriendi medievais, uma vez que o autor não encara o fim da estadia terrena propriamente como uma agonia, mas como uma separação natural da alma e do corpo, a inevitável quebra de um todo que se despede definitivamente, para dar início a uma nova existência.

Reconhecendo a necessidade de corrigir o mal e salvaguardar os interesses mais elevados, o cardeal romano defende que a Arte de Bem Morrer é, indiscutivelmente, artium omnium maxima (Bellarmino, 1620, p. 2), dado que todos têm de prestar contas ao Criador. Num julgamento em que o Diabo promove a acusação, a consciência serve de testemunha - nem sempre abonatória - e Deus é o juiz que absolve ou condena à morte eterna. Deste modo, as almas dos moribundos que nunca meditaram devidamente sobre o fim dos seus dias avançam turbatim para as portas do inferno. No intuito de evitar esse desfecho miserável, Bellarmino propõe uma alternativa laboriosa, começando por refletir sobre a natureza da morte. Concebe-a como uma manifestação do mal, porque aniquila a vida, mas lembra que foi criada por Deus, que só gerou coisas boas, pelo que não pode ser absolutamente má. Conclui-se, assim, que tudo depende da forma como se leva a vida, pois a paixão de Cristo abriu caminho para a ressurreição eterna, e aponta-se as vantagens da libertação corporal, que vem pôr fim às maleitas humanas. Ora, é precisamente por esse lenitivo que anseia D. Fabrizio quando o toque de finados lhe suscita o desejo da serenidade mórbida, uma tranquilidade que já nem o ambiente campestre lhe podia proporcionar: "Dalla Madre Chiesa vicina giungevano lugubri i rintocchi di un mortorio. (...) Questa effimera identificazione con un defunto inoto fu 
sufficiente a calmarlo. «Finché c' è morte c' è speranza» pensò; poi si trovò ridicolo per essersi posto in un tale stato di depressione perché una sua figlia voleva sposarsi." (p. 65).

Este é o primeiro momento do romance em que a fúnebre volúpia do protagonista começa a revelar-se, ainda que por breves instantes, na sequência de um delicado episódio familiar que o leva a procurar uma forma de evasão. Mais do que um refrigério, a morte, lembra o cardeal, promete a entrada no reino celeste, para todos os que viveram ao serviço de Deus, porque liberta a alma da prisão carnal e coroa os justos de glória. Mesmo para os que ficam no Purgatório, o abandono da vida terrena é já sinal de fuga aos infernos e esperança de felicidade eterna, pelo que, para os pios, a morte não ostenta uma "faciem horrendam, sed blandam, non terribilem, sed amabilem", como recorda o prefácio de Bellarmino, invocando a autoridade de S. Paulo, que entende o fim da vida como uma forma de aproximação a Cristo. Nestes termos, a morte só assusta os pecadores, porque aos olhos de quem vive na graça de Deus, ela apresenta-se útil, salutar, amável e até desejável, como comenta o autor da Ars bene moriendi no final das palavras introdutórias.

Cumpre, então, questionar, no âmbito deste estudo, até que ponto o corteggiamento della morte cultivado pelo Príncipe se aproxima da postura preconizada pelo jesuíta. Lampedusa não poderia deixar de refletir no seu romance a mundividência barroca, tão arreigada na identidade cultural siciliana, e essa influência torna-se particularmente expressiva no tratamento do tema tanatológico. A perspetiva individual não pode demarcar-se totalmente das coordenadas que, na vida e na morte, submetem o seu desenvolvimento à interferência determinante do espaço envolvente, do tempo presente e da cultura vigente.

A pastoral da morte permite delimitar um espaço peculiar de enunciação da vida, nas suas etapas e formas de exteriorização fundamentais. Antepõe-se, por isso, como meta e objetivo ideal ao aperfeiçoamento do indivíduo e, enquanto tal, responde a uma conceção sacralizante de pensar a evolução da sociedade (ARAÚJO, 1997: 205). Neste sentido, a vivência da morte oferece uma oportunidade extraordinariamente fecunda para interpretar a visão histórico-social do duque de Palma, que se reflete no olhar desencantado do Príncipe de Salina. Lampedusa moldou o seu protagonista no seio da realidade siciliana, na época em que a mentalidade barroca começou a ceder à uniformização imposta pela unificação. Fabrizio representa, portanto, a velha classe decadente e os valores antigos, pelo que se torna pertinente procurar no código sistematizado por Bellarmino a chave de leitura para perceber os diferentes passos do processo de contemplatio mortis que marca a cadência do romance. 


\section{A ILUSÃO DE BEM VIVER}

Alívio para a dor e bem-aventurança, são estas as aliciantes promessas com que o cardeal jesuíta alicia os leitores para os converter à crença de que só uma vida boa - entenda-se piedosa e casta - pode conduzir a uma morte boa, ou seja, sem temer o juízo final. Esta é a tese que defende logo no primeiro artigo, o que nos convida a questionar, à luz da leitura comparada que pretendemos concretizar, em que medida o Príncipe de Salina cumpre essa premissa, enquanto cristão praticante. Qual seria o veredicto se a sua conduta de vida fosse submetida ao julgamento final?

A abertura do romance coloca intencionalmente o patriarca na sua função de líder espiritual da casa, conduzindo a peregrinação simbólica pelas contas do rosário. No entanto, ainda no capítulo inicial temos oportunidade de confirmar que vive a religiosidade de forma aparente, servindo-se até da proteção eclesiástica, na figura do Padre Pirrone, para dissimular as suas incursões noturnas nos prazeres mundanos. Este comportamento contraditório denuncia a sua incapacidade para abandonar os vícios carnais, como exige o segundo artigo do manual de bem morrer, desprezando riquezas, honras e prazeres. Note-se, contudo, que este apelo ao comedimento como estratégia de elevação espiritual não é, de resto, exclusivo da mensagem cristã, uma vez que se inscreve numa ancestral tendência para valorizar a dimensão intelectual do homem. O Fédon de Platão equiparava a filosofia a "um treino de morrer e de estar morto" (64a) e também os estóicos sustentavam essa conduta impassível, como se depreende das palavras de Séneca: "Deve-se aprender a viver durante toda a vida, e por mais que tu te possas admirar, deve-se aprender a morrer durante toda a vida."6.

Em nenhum momento D. Fabrizio renuncia às suas propriedades, antes pelo contrário, vive aterrorizado pela perda desses mesmos bens, garantia da sua supremacia, e assiste com inveja ao crescimento da fortuna de D. Calogero. E, no que diz respeito às glórias terrenas e aos deleites sensoriais, percebemos que só desiste deles quando o marasmo lhe tolhe os sentidos e anestesia a vontade. Poder-se-ia argumentar que revela um certo desprendimento ao recusar o cargo de senador oferecido por Chevalley, mas este não é um gesto de verdadeira humildade. A renúncia significa despeito e orgulho ferido, numa última tentativa de pugnar pela sua dignidade, perante o reconhecimento da inevitável substituição de castas implementada pelo Risorgimento. Para Schopenhauer, a fidelidade aos princípios é o traço que distingue um homem nobre resistência ${ }^{7}$.

Apesar de enredado nas vicissitudes mundanas, D. Fabrizio procura manter uma aparência de fé, mas a sua altivez perante as admonições do Padre Pirrone comprova que a falta de verdadeira convicção religiosa o impede de alimentar a esperança, que, nas palavras de S. Paulo (Rom. 5), 
reflete uma "boa consciência". Além disso, a existência marcada pela amargura impede o aristocrata de praticar a caridade, esse dom de Deus que habita apenas nos corações bons. Também neste capítulo a conduta do Príncipe peca, porque não demonstra particular preocupação com o sofrimento dos seus súbditos, nem tão pouco com os problemas dos próprios familiares. Insensível à paixão de Concetta, inflexível perante os ciúmes do filho, imperturbável face à histeria da mulher, o patriarca evita qualquer manifestação de abertura ao próximo. Mesmo as concessões que permite a Tancredi são mais obrigações do que sinais altruístas de boa vontade, uma vez que age de modo a garantir-lhe segurança económica e uma confortável posição social, não por acreditar verdadeiramente que está a contribuir para a felicidade do sobrinho, até porque reconhece nele um dos responsáveis pela ruína da sua classe ${ }^{8}$.

Para além das virtudes teologais, Bellarmino contempla ainda, no quarto capítulo, a importância da castidade e do arrependimento, apelando à necessidade de o homem exercitar diariamente a sua faculdade de introspeção, de modo a reconhecer as suas faltas e pedir perdão. Este é um procedimento que o senhor de Salina pratica, ao meditar criticamente sobre a sua visita a Mariannina. Admite, portanto, o seu duplo pecado, diante da lei de Deus e do afeto de Stella, mas imediatamente considera inútil a tentativa de confissão junto do padre e adota uma estratégia que conduz à justificação do seu erro, mediante um curioso diálogo interior que culmina na lógica absolvição das suas fraquezas, atirando a culpa para a frivolidade da mulher (p. 29).

A cegueira e a presunção de imunidade condenam o patriarca da casa de Salina a incorrer no erro dos ricos, amplificado pelo cardeal romano no capítulo $\mathrm{V}$, no qual reduz os grandes latifundiários a meros arrendatários das propriedades divinas, lembrando que os homens são simples gerentes provisórios da criação de Deus, pelo que de nada vale apegar-se aos bens terrenos, uma vez que podem perder o direito a usufruir deles, caso se mostrem indignos da confiança celeste. Esta sábia perspetiva encontra facilmente eco nas paredes da casa de Salina, repletas de quadros evocativos dos feudos perdidos pelo desgaste temporal ou pela luxúria desregrada dos administradores, lembrando que a moderação dos costumes é o melhor instrumento de manutenção do património (p. 33).

Alicerçando sempre a sua argumentação nos textos sagrados e seus comentadores, Bellarmino institui a sobriedade, a justiça e a piedade como virtudes basilares, de modo a promover a harmonia entre os homens e a semelhança com a perfeição divina. O protagonista de Il Gattopardo, porém, não parece particularmente influenciado por nenhuma delas. O seu carácter irascível e voluptuoso, salientado pela expressiva adjetivação dos populares "grande, rabbioso e orgoglioso" (p. 163), põe em causa a temperança, ao mesmo tempo que a insensibilidade face às desigualdades sociais 
compromete o seu sentido de equidade, pois as suas preocupações cingem-se à esfera do seu estatuto privilegiado. No que diz respeito à pia relação com o divino, cumpre concluir que a fé do Príncipe suscita muitas dúvidas, como veremos mais em pormenor. Depois de definir as virtudes essenciais, o autor do manual De arte bene moriendi passa a indicar as boas obras consequentes, porque a piedade, que se volta para Deus, promove a oração, a sobriedade impele o corpo ao jejum e o desejo de justiça acicata a generosidade da esmola e a intervenção social. No que diz respeito ao primeiro fruto virtuoso, recordamos que o Senhor de Donnafugata só reza na presença da família, o que atenua o grau de recolhimento interior e enfatiza a natureza ritual da prece, contrariando o isolamento instituído por S. Mateus (Mt. 6.5-6). Além disso, a atitude suplicante não incute no patriarca a humildade, a caridade, o conforto, a confiança, a elevação e o deleite prometidos pelo cardeal romano, uma vez que a récita familiar se resume a uma repetição monótona de "palavras soltas", sob o olhar soberano dos deuses pagãos, que logo recuperam o seu domínio nas restantes vinte e três horas e meia. Terminado o suplício, "a prepotência ansiosa da Princesa fez cair secamente o rosário na bolsa" e o marido, ao levantar-se, fazia tremer o chão como se quisesse marcar "o orgulho desta efémera confirmação do seu domínio sobre os homens e sobre a casa" (p. 16). Sem o ímpeto da devoção, as preces não alcançam os ouvidos divinos, pelo que reconhecemos nesta rotina mais um sinal de falsa religiosidade do que uma manifestação de fé.

Relativamente ao preceito de abstinência, apontado por Bellarmino como forma de purificar a alma através do sacrifício do corpo, não há referências explícitas no romance. No entanto, há um momento significativo em que o tio de Tancredi se encontra diante de uma opípara mesa, repleta de preciosidades gastronómicas, mostrando-se totalmente indiferente a esta tentação gulosa. Este desdém não é, de facto, motivado pela obrigação de jejuar, mas revela o fastio causado pelo vazio interior, não como forma de depuração, mas antes como sinal de uma consciência maculada pelo pecado. Também no que se refere à esmola, o governante de Salina revela uma atitude pouco cristã. A altivez contrasta fortemente com a humilde generosidade dos seus súbditos, que lhe oferecem os seus melhores produtos, na tentativa de agradar ao soberano. Anojado com aquele espetáculo de sangue e de odores fortes, o aristocrata retribui com desdém os gestos de sincera submissão, que suporta com a cordialidade de quem reconhece a conveniência de agradar aos pobres, numa inútil tentativa de emprestar a Deus (Mt.25).

Embora totalmente alheio aos benefícios profundos das boas obras, o senhor de Salina tem consciência da sua necessidade e ostenta grande reverência pelos sacramentos que o jesuíta de Montepulciano coloca no cerne da vida cristã. A partir do capítulo $\mathrm{X}$, o manual De arte bene 
moriendi passa a enunciar os sagrados instrumentos através dos quais a Igreja procura alimentar a perseverança dos fiéis, a começar pelo Batismo e pela Confirmação, que não são referidos no romance, embora estivessem naturalmente integrados na educação do príncipe. Focando a atenção na Eucaristia, que assume particular significado na chegada a Donnafugata, percebe-se que a família usa a igreja como palco oficial de boas-vindas, visitando-a mesmo antes de entrar no Palácio, contíguo ao Duomo. Forma-se, então, um cortejo onde os homenageados desfilam com a imponência empoeirada pela viagem, ao lado das autoridades locais. Acolhidos com a costumada hospitalidade na casa do Senhor, a prole dos Salina ocupa o coro para ser devidamente admirada pela multidão de curiosos, e assiste ao breve ritual, cumprindo a sequência das genuflexões, as vénias ao altar e o restante cerimonial, que mais parece um desfile de vaidades pessoais. O paterfamilias exibe-se com euforia, a mãe esforça-se por manter a pose, lutando contra o calor e cansaço, Tancredi e Concetta entretêm-se com jogos de delicada sedução. Esta cena de total desprezo pelo fervorino pouco convincente do monsenhor Trottolino não corresponde, de todo, à conceção que Bellarmino apresenta da missa como local dedicado à sagrada Comunhão com o corpo de Cristo, alimento e remédio dos pecadores, uma vez que a Eucaristia, neste contexto, serve apenas como formalidade e não como um momento de efetiva devoção e ação de graças.

Bellarmino prossegue com a Penitência, uma ausência significativa no romance de Lampedusa, e aborda, de seguida, os Sacramentos que pressupõem um compromisso vitalício: a ordenação para os clérigos e o matrimónio para os leigos. No que diz respeito ao primeiro, o manual começa por lembrar os deveres de castidade, de dedicação exclusiva à messe divina e de pia entrega ao serviço eclesiástico. Estes preceitos contrastam claramente com a vassalagem quase aviltante imposta pelo Príncipe ao padre Pirrone, tornando-o conivente com os seus pecados e colocando, assim, em causa o regime de exclusividade do clérigo. Além disso, as preocupações mundanas, e pessoais, do jesuíta de Cono face à ameaça da guerra, a sua falta de confiança na proteção dos céus e o modo pouco ortodoxo como resolve os problemas familiares inviabilizam, por completo, a sua garantia de salvação eterna. Importa ainda lembrar outro momento da obra em que se sugere a dependência dos ministros de Deus à casa de Salina. Referimo-nos à tradição secular de visitar o mosteiro do Santo Espírito, no dia seguinte à chegada a Donnafugata. Sob o pretexto de homenagear o túmulo da Beata Corbèra, antepassada do clã, o Príncipe saboreia a vã gloríola de usufruir de um privilégio partilhado apenas com o Rei, mediante o qual tinha a excecional prerrogativa de quebrar a clausura das religiosas. Não será decerto despicienda a alusão à cordial solicitude com que as freiras recebiam a visita e guardavam as dez onças que o benemérito D. Fabrizio deixava discretamente sobre a mesa 
do refeitório, insinuando uma tácita permuta de favores e condescendências que garantiam aos visitantes um certo ascendente, genético e económico, sobre a ordem (p. 77).

Estas práticas não estariam certamente em consonância com o exemplo de Cristo, esposo enamorado que se sacrificou por amor à sua Igreja. Bellarmino recorre a Ele como modelo para os religiosos e para os cônjuges. Em conformidade com a união estabelecida e abençoada pela aliança sagrada do matrimónio, o cardeal aconselha os casais a pautar a sua vivência comum pelo objetivo de frutificar a relação, sempre com os olhos postos na fidelidade e na graça de Deus. Stella testemunha claramente esta mentalidade, no que diz respeito à procriação e à visão preconceituosa da sexualidade. O marido, pelo contrário, situa-se no extremo oposto, dado que não mantém um amor casto nem fiel, chegando a repudiar a mulher por causa da pudicícia que lhe parecera encantadora no início, mas que se tornara repelente com o decorrer dos anos. A relação libidinosa de Tancredi e Angélica, afasta-se igualmente do amor puro que Cristo dedicou à sua esposa, sempre submissa e reverente como compete ao elemento feminino. Não admira, pois, que o manual de Bellarmino estipule como preceito de bem viver a obediência, a paciência e o silêncio das mulheres, a quem os cônjuges teriam de educar e até corrigir, valendo-se da sua supremacia. Assim procede D. Calogero e também deviam atuar os homens da família Salina. No entanto, o marido de Stella não consegue reprimir as crises histéricas da mulher traída, nem promove a harmonia no lar. A sua visão da vida nupcial parece contaminada pelo pessimismo de quem encara a paixão como um antecedente inevitável da desilusão e da quebra de expectativas (Schopenhauer, 2004: 145).

Seguindo o natural percurso da vida, a derradeira reflexão do primeiro livro da arte de bem morrer aqui tomada como referência debruça-se sobre a necessidade de administrar o último Sacramento. Tomando como mote a prece purgatória que o ritual reserva para cada uma das portas do corpo que cedem passagem ao pecado, ou seja, cada um dos cinco sentidos que devem ser contidos pela temperança, Bellarmino (1620, p. 262) aconselha os homens a purificarem o espírito, não só na iminência da morte, mas também durante o percurso da vida. Deste modo, a prudência profilática manda que o mortal se abstenha de macular a alma com a concupiscente observação de mulheres bonitas, ao mesmo tempo que proíbe os ouvidos de dar atenção a mentiras, injúrias, bajulações ou propostas sedutoras que alimentam as querelas e os contactos voluptuosos. O cheiro é considerado inofensivo para a alma, mas o paladar deve evitar a gula e a embriaguez. O tato, por sua vez, tem de ser submetido a um regime de abstinência e pudica moderação. Este estatuto de controlada temperança, segundo advoga o cardeal, só pode ser alcançado através de muitas horas de 
meditação profunda nas Sagradas Escrituras e de uma constante ocupação útil do espírito, de forma a minimizar as perigosas oportunidades concedidas pelo ócio.

A ociosidade surge, enfim, como o grande causador dos pecados de Fabrizio, uma vez que a falta de afazeres lhe causa tédio e o incita a procurar o divertimento fácil, a efémera satisfação dos pequenos prazeres sensuais. Daí que o patriarca de Salina não resista ao deleite visual proporcionado pela contemplação da fascinante beleza de Angélica e sinta prazer em imprimir um tom ameaçador às palavras com que assusta a mulher e repreende os filhos. Peca também pelo olfato quando se deixa anestesiar pelos requintados odores do jardim palaciano ${ }^{9}$ e pelo perfume de bouquet à la Maréchale que exala dos cabelos da sua acompanhante na valsa, o que lhe atiça a curiosidade sobre o aroma dos seus lençóis. O Príncipe cede igualmente à volúpia do paladar, porque não resiste ao gosto delicado da gelatina multicolor aliada ao inebriante travo do rum (p. 43), e delicia-se com o toque das sensuais habilidades de Mariannina, "Una specie di Bendicò in sottanino di seta"( p. 30).

Em traços gerais, esta breve perspetiva sobre a conduta do senhor de Salina através da lupa dos preceitos de bem viver enunciados pelo catecismo do cardeal romano indica que o Príncipe, apesar de manter uma aparente máscara de cristão praticante, não cumpria, de modo algum, as normas estipuladas para orientar os comportamentos adequados ao homem virtuoso. D. Fabrizio falhou, portanto, no longo tirocínio de preparação para a vida eterna que ocupa o primeiro livro do manual de Bellarmino, subvertendo por completo, na vivência íntima, os conselhos das Sagradas Escrituras. Resta agora averiguar se o nobre caçador também errou o alvo no momento decisivo do fatal disparo.

\section{A ARTE DE BEM MORRER}

$\mathrm{Na}$ dedicatória ao cardeal Francisco Sfortia, Bellarmino define a sua obra como um "Livro de exígua erudição, mas de grande utilidade", salientando o objetivo prático do volume, cuja segunda parte é dedicada à morte iam uicina.

Nesta circunstância, adverte-se, em primeiro lugar, para a meditatio mortis, de modo a encarar o derradeiro suspiro como a natural libertação da alma, destinada à existência eterna, em vez de temer o seu rosto assustador. Além disso, o cardeal lembra ao homem a imprevisibilidade do fim, aconselhando a prática diária de dois instantes de introspeção e remissão das faltas, para que a alma se mantenha limpa de pecados que a possam comprometer. Segundo o manual, também os quatro novíssimos (morte, juízo, inferno e paraíso) devem constituir motivo de contínua ponderação, para que nunca se apague da mente humana a ameaça do julgamento final. 
No romance, este exercício reflexivo vai ganhando um lugar de crescente destaque e assume diferentes modulações que importa analisar. Em primeiro lugar, a cena do militar encontrado morto no jardim, com as vísceras de fora, evoca a tendência pictórica dos séculos XIV-XVI para representar o cadáver meio descomposto ou envolto na mortalha. Este tipo de figuração, pouco frequente nas artes moriendi, embora fosse comum em livros de horas, serve precisamente para presentificar os horrores da decomposição, apelando a uma estratégia descritiva que recorda a devastadora mortandade provocada pelos surtos de peste, pelas crises demográficas e pela guerra. A reprodução dos sinais de putrefação acentuou-se no século XVII, comportando uma certa reanimação do sadismo, que se torna visível nos pormenores iconográficos dos sacrifícios dos mártires e nas descrições literárias dos suplícios que abundam na era barroca, particularmente atraída pelo sofrimento macabro e pelos sinais visíveis da tortura do corpo (ARIES, 1977, p. 92-97). Esta visão do cadáver mutilado, fortuitamente abandonado num lugar idílico para acentuar a imprevisibilidade e o horror fúnebre, oferece, portanto, um motivo persuasivo para a meditação mórbida. A família Salina, porém, resiste a fazer uma leitura mais profunda do sucedido. O Príncipe limita-se a chamar os militares no intuito de fazer desaparecer o defunto, para alívio de todos, e acrescenta à oração diária um De profundis pela alma do falecido. Pretendia acalmar, deste modo, alguns pensamentos incómodos que atormentavam a sua consciência, habituada a aceitar com resignação o sacrifício dos mártires sacrificados em nome do ideal monárquico, mas profundamente abalada pelo confronto com uma morte fortuita e inexplicável (p. 19).

$\mathrm{Na}$ verdade, este momento lúgubre desponta, no patriarca, a cogitação sobre o sentido da vida que, já em Donnafugata, evolui para um desejo de mórbida pacificação, ao dobrar dos sinos. No entanto, o auge desse mecanismo introspetivo é atingido no grandioso capítulo do baile, enfatizado pelo contraste entre a euforia dos convidados e a angústia do magnânimo Leopardo, plenamente consciente da ruína do seu mundo, tal como anunciara a Chevalley. Não será despiciendo notar que o protagonista se condói da sua presença ofuscada pelo esplendor de Angélica, pelo heroísmo fanfarrão de Pallavicino, pelo garbo de Tancredi e até pelo ridículo de Calogero, que atraía as preocupações da família e toda a curiosidade dos convivas. Não surpreende, pois, que Fabrizio se sinta deslocado num ambiente em que já não ocupa o lugar central, errando pelos salões povoados de mulheres pouco atraentes e de homens entediantes, num cenário de decrépita sumptuosidade. Essa melancolia transformada em humor negro suscita-lhe um forte anseio pelo isolamento, ao abrigo das conversas mesquinhas. 
De facto, o Príncipe de Salina aparece agora indiferente às solicitações mundanas, recusandose a pactuar com um mundo em que já não é herói, uma realidade povoada por burgueses como Sedàra, que ousam decretar a extinção dos aristocratas. $\mathrm{O}$ tio de Tancredi pressente que os palácios serão ocupados por sombras fúnebres e os solares revestidos de ouro estarão condenados a desaparecer, mas não poderia adivinhar, como lembra o narrador, que nem os deuses pintados nos frescos do teto iriam escapar à destruição do século XX, na sequência dos bombardeamentos de 1943 (p. 188). Este é talvez o ponto do romance em que se torna mais evidente a colagem de perspetivas entre o protagonista e o responsável pela narrativa, partilhando a certeza de que é inútil alimentar a ilusão da eternidade, quando a morte é a única certeza. O baile torna-se, então, aos olhos do clarividente Príncipe um espetáculo de irrisórios enganos, de fingida felicidade, pelo que procura o erudito silêncio da pequena biblioteca, iluminada e vazia. Aí, refresca as ideias com um gole de água pura e encontra a serenidade necessária para antever a sua partida da morada terrena, quando, numa espécie de revelação premonitória, deposita os olhos na cópia do quadro de Greuze.

Depois de alguns instantes de reflexão, o aristocrata desenvolve uma clara empatia com a cena retratada, percebendo a intenção contemplativa do amigo Diego, ao selecionar uma das telas do díptico dedicado pelo pintor francês ao tema da maldição paternal. De resto, a visão moralizante que o artista traçou no quadro que batizou como Le fils puni adequa-se perfeitamente ao esquema mental deste romance pois, como acentua Francesco Orlando (1998), a obra entrelaça a vida íntima e a História. É preciso advertir, no entanto, que a imagem apresentada por Lampedusa como 'A morte do Justo' coloca em evidência a dor de um filho que tinha abandonado o lar e, ao regressar, encontra o pai no leito de morte. A alteração onomástica sugere uma intenção marcada de manter a focalização no Pai, uma vez que só assim o orgulhoso Leopardo se poderia identificar com o morto, desencadeando uma eloquente myse en abime que antecipa o capítulo seguinte (NIGRO, 2006, p. 31). Como se estivesse diante do reflexo de um espelho, D. Fabrizio prevê o seu trespasse, antecipando o comportamento dos filhos e concluindo que o cenário seria muito semelhante àquele que Greuze havia recriado para ilustrar as barreiras entre corações que bombeiam o mesmo sangue.

Para interpretar a reação do Príncipe perante a imagem sepulcral, importa não perder de vista o manual de edificação que nos serve de paradigma e cumpre lembrar que a sensibilidade estética do universo Cristão habituou o homem, desde longa data, a colocar os olhos sobre representações fúnebres. O fim dos tempos entrou na iconografia religiosa a partir do século XII, altura em que as fachadas começam a ser decoradas com cenas apocalípticas de Jesus liderando a ressurreição dos mortos e o castigo dos ímpios (ARIES, 1977, p. 122-124) ${ }^{10}$. Estas figurações funcionam, pois, como um espelho que promove uma estratégia retórica muito eficaz, tendo em conta que a sua persuasiva 
mudez rememorava a precariedade da vida terrena, num exercício de contínua purgação. É precisamente esse o efeito do quadro que surpreendeu o Príncipe num momento de particular debilidade, quando buscava um refúgio longe das futilidades mundanas, numa atitude provocada mais pelo despeito do que pela sábia abnegação. De facto, o aborrecimento do tio de Tancredi e a sua visão fatalista foram acicatados pela humilhante comparação com outros bailes, onde brilhara como estrela polar, mais jovem e mais forte. A dura consciência de que começa a entrar no Outono da vida torna-o mais sensível à Morte do Justo, mas essa constatação traduz-se apenas na decisão de agilizar as questões logísticas para garantir uma digna morada eterna, sem, contudo, conseguir alterar substancialmente a sua preparação interior.

Fugindo à desconcertante meditatio mortis, o pai de Concetta deixa-se iludir de imediato pelo desafio dos noivos que interrompem o seu momento de introspeção com um convite para regressar à ribalta. Estes são ainda demasiado novos e ambiciosos para parar e contemplar a mensagem de Greuze, a morte é, para eles, uma preocupação alheia. Com Angélica nos braços, os sentidos do velho Leopardo reanimam-se e forjam uma sensação momentânea de rejuvenescimento, recordando a juventude feliz, "quando ignorava ancora cosa fossero le delusioni, il tedio, il resto. Per un attimo, quella notte, la morte fu dinuovo ai suoi occhi «roba per gli altri»" (p. 192). Emanam desta visão desencantada do percurso biográfico algumas afinidades com a posição pessimista de Schopenhauer (2004, p. 54), para quem a vida representava apenas um vertiginoso processo de deterioração. E, na verdade, os acontecimentos que sucederam, no romance, ao apogeu da valsa confirmam essa descida a grande velocidade, intensificando o desapontamento do Príncipe. Os requintes do banquete enfastiam-no. Os lugares disponíveis, desprezados pelos outros, obrigam-no a ocupar uma posição incómoda, ao lado do general Pallavicino, um dos agentes da aviltante Unificação que o expulsava do seu reino. Além disso, o ousado militar lança-lhe uma premonição de desgraça, que lhe aperta o coração, quando lembra que nem as estrelas fixas são verdadeiramente fixas. Entendendo esta prolepse inquietante como um sinal de terríveis mudanças, o astro polar da constelação Salina espera, com ansiedade, o término do baile anunciado pelas mesas vazias e pelo lento apagar dos castiçais, cuja chama cobre o salão de uma penumbra de mau augúrio.

Começa, então, a raiar a aurora de um novo dia, vencendo as efémeras velas com a sua luz natural, tal como a morte triunfa sobre a vida com a promessa de uma existência mais verdadeira. Em vez de regressar a casa, D. Fabrizio aprecia a frescura da alba e procura a companhia das fiéis companheiras celestes que o escoltam ao longo do percurso através da imundície urbana. As estrelas fazem-no suspirar por um encontro perene na esfera sideral, abrindo finalmente o caminho para uma 
profunda meditação sobre a morte. Desânimo, pessimismo, tédio: eis o resultado da reflexão que leva o senhor de Salina a desejar o fim dos seus dias de sofrimento.

A ameaça do fim só viria, no entanto, a concretizar-se vinte e um anos depois do baile, apesar de o romance apresentar um significativo hiato entre os dois momentos, como se o Príncipe tivesse realmente deixado de viver naquela noite em que anteviu a morte e a sentiu bem perto. A aproximação não parece, contudo, ter resultado numa efetiva alteração de comportamentos, como preceituava o manual de Bellarmino, nem fez com que o protagonista começasse a acreditar na ressurreição das almas. Pelo contrário, Fabrizio encara o derradeiro suspiro como o desfecho completo e em nenhum momento recorre à introspeção como forma de arrependimento, nem tãopouco toma em consideração os novíssimos do homem. Embora se afirme como cristão praticante, o orgulhoso Leopardo já não deposita esperança em si, nem confiança nos homens, nem fé em Deus. Consome os últimos anos a recordar as memórias remanescentes de um nobre passado, decidido a desistir de viver, não como forma de purificação ou de castigo, mas antes como desesperada manifestação de autonomia e altivez. O encerramento do seu coração, totalmente abúlico, a qualquer expectativa falaciosa subentende uma renúncia ao futuro como técnica de autodefesa que pressupõe já uma forma de aniquilação. Esta resolução de cortar o fio tecido por Cloto representa, porém, uma tremenda ousadia porque tenta inutilmente usurpar uma prerrogativa divina, ao mesmo tempo que menospreza o Juízo Final.

O segundo preceito enunciado pelo cardeal de Montepulciano na parte dedicada à iminência da morte insiste precisamente na importância do julgamento individual post mortem. Bellarmino tranquiliza, porém, os homens puros, que têm a seu favor seis argumentos: a infalibilidade da Justiça de Deus, o exemplo de Cristo ressuscitado, a recompensa dos bons, o castigo dos hipócritas, a libertação do corpo e a avaliação dos atos cometidos e suas consequências, boas ou más (BELlaRMino, 1620, p. 198-211). Esta cena forense, a que o moribundo só tinha acesso depois de transpor as portas da eternidade, não atormenta a presunção de D. Fabrizio. Senhor de si mesmo até na morte, encarrega-se de fazer o balanço da sua existência terrena, e confessa que a sentiu esvair-se lentamente durante anos, com a inexorável cadência dos grãos de areia a passar pela ampulheta (p. 201). Esse longo e penoso esvaziamento do fluido vital provocou-lhe uma gradual desconstrução da personalidade, que se ia diluindo na realidade cósmica, de acordo com as leis de Lavoisier, sem que os outros se apercebessem dos efeitos da erosão. Todos lhe foram indiferentes, exceto Tancredi, mais atento ao progressivo desgaste do Zione pela genética empatia que os unia. O lento processo mecânico de redução ao pó original ganha, porém, uma velocidade turbulenta nas últimas páginas do romance, semelhante à cascata do Reno. A comiseração familiar confirma a derrocada iminente, 
acentuando a consciência de que o homem deitado no hotel Trinacria ${ }^{11}$ mais parece uma sombra da imagem que ostentava ainda no capítulo anterior. A surpreendente decadência do protagonista surpreende o leitor, quando o vai encontrar recém-chegado de Nápoles, onde recebera do médico a irrevogável sentença ${ }^{12}$.

Inicia-se, então, o desenrolar de um compasso sepulcral que segue paulatinamente o ritual de irreversível despedida definido por Bellarmino, embora este não previsse a intervenção do médico. De qualquer modo, o papel do físico revela-se perfeitamente inócuo, pois a debilidade da sua aparência não oferece qualquer credibilidade aos recursos da medicina. $\mathrm{O}$ narrador ridiculariza a tentativa incipiente de resgatar um corpo já contaminado pelo pó, pelo odor a remédios e pela urina que anunciava a derrota física. $\mathrm{O}$ ambiente pesado do quarto de hotel asfixia o moribundo, que pede para ser transportado até à varanda, de modo a contemplar o mar, invadido por um certo torpor que o convida a refletir. É então que o Príncipe abre a sessão do seu Juízo final, ocupando o lugar de réu e de juiz, num impressionante monólogo interior ${ }^{13}$ que culmina com o irónico cálculo matemático: “Ho settantatré anni, all' ingrosso ne avrò vissuto, veramente vissuto, un totale di due...tre al massimo. E i dolori, la noia, quanti erano stati? Inutile sforzarsi a contare: tutto il resto: settant' anni"' (p. 210).

Esta contabilidade, perfeitamente enquadrada no perfil de um homem dedicado às ciências numéricas, exprime subtilmente o reconhecimento do fracasso desse mesmo conhecimento. D. Fabrizio parece subjugar a razão à supremacia das emoções, admitindo que a vida vale pela intensidade das experiências vividas e não pela soma de dias ou de bens. O balanço conclusivo fá-lo recordar "as palhas douradas" por entre "o imenso monte de cinzas" que representava a sua vivência terrena, povoada por ténues raios de transitória felicidade: o entusiasmo do noivado, que deu origem a um casamento fracassado; o nascimento de Paolo, que depois se revelou um herdeiro indigno; as conversas com Giovanni, que cedo abandonou a família; as observações astronómicas, que lhe revelaram a infinidade do universo e a impossibilidade de atingir o Absoluto. Estas horas de antecipação das "beatitudes mortuárias" ditam, portante, uma sentença de frustração eterna que consume as últimas forças do Príncipe. Depois de reconhecer o balanço dramático, relembra ainda com ternura os cães fiéis, alguns cavalos, as jornadas de caça com Tumeo, as prestigiantes visitas ao convento, o orgulho no caráter de Concetta, os fugazes êxtases amorosos, a homenagem pública da medalha recebida na Sorbonne, o suave toque de uma gravata de seda e o sedutor olhar das mulheres com que se cruzara ao longo da vida, sobretudo das que não chegara a possuir. 
Desta enumeração arbitrária de uma vida repartida por vários cenários de engano resulta, enfim, uma sentença mais cruel que a entrada nas moradas infernais. Nenhum castigo se revelaria mais doloroso para quem procurou sempre vencer as leis do esquecimento do que a noção de vazio. A D. Fabrizio, de nada valeriam, portanto, os argumentos apresentados por Bellarmino, uma vez que não temia o panorama de horror descrito com algum pormenor pelo manual De arte bene moriendi ${ }^{14}$. Note-se, todavia, que, embora o romance não descreva a entrada do patriarca nas gehennae inferiores, sugere uma simbólica reprodução desse ambiente de horror na viagem que conduz o doente até ao leito de morte, a bordo de um comboio metaforicamente referenciado como "máquina infernal", lembrando que este instrumento do progresso se alimentava de fogo e cuspia fumo. Não deixa de ser significativa a decisão obstinada do senhor de Salina no sentido de utilizar esse meio de transporte para voltar ao seio materno, como se respondesse, assim, ao apelo da terra que se preparava para acolher o principesco invólucro material. Na companhia da filha Concetta e do neto Fabrizietto, foi suportando o trajeto comparado a uma "viagem fúnebre", onde não faltou o odor acre e o ruído exasperante, pelo que a jornada mais parecia uma teimosa incursão no reino de Hades, tendo em conta o tormento infligido ao já debilitado passageiro, que pela última vez faz valer a sua autoridade (p. 203). Terminada a catábase, o extenuado viajante sucumbiu ao desmaio, perdendo definitivamente o controlo sobre os seus passos.

Todos os esforços para encorajar o moribundo eram já improfícuos, como inútil seria falar ao Príncipe da promessa de bem-aventurada glória, prevista pelo cardeal Romano no quarto preceito do segundo livro. O último novíssimo teria lugar no paraíso, altíssimo local acima de todas as estrelas, onde permaneceria por toda a eternidade e com direito a usufruir do cúmulo de todos os bens. Desse privilegiado posto de observação, o astrónomo siciliano poderia concretizar o sonho de contemplar de perto os astros, ver a plenitude do orbe terrestre, experimentar a suprema felicidade de uma existência pura, infinitamente livre de dor, de sofrimento e de preocupação. De facto, essa era a única glória que o senhor de Salina poderia conceber, porquanto ambicionara ultrapassar o horizonte humano e tocar o inatingível através do observatório, o seu local sagrado de elevação espiritual, o seu manancial de glória eterna.

Por conseguinte, essa é a sua herança mais preciosa, na hora de redigir o testamento. $\mathrm{O}$ compêndio de Bellarmino sublinha a necessidade de entregar os bens em vida para aliviar a carga da alma, consignando, em primeiro lugar, o pagamento de dívidas e depois a distribuição das riquezas, sem esquecer a esmola dos pobres e os emolumentos das missas indispensáveis à salvação da alma. Na hora da despedida, o "Fabrizio" elabora mentalmente uma espécie de relação de bens, suscitada pela observação das suas propriedades, entrevistas ao longe a partir da varanda do hotel. Deitado 
num leito estranho, o lugar que recorda, em primeiro lugar, é precisamente o estúdio astronómico, que imagina destinado a "decénios de pó". Tudo, afinal, se resume a poeira: o corpo, as requintadas mobílias (alcovas de amor e leitos de morte), as casas, as propriedades. Todos os bens terrenos estão, condenados ao aniquilamento material, pelo que o felino moribundo, qual náufrago em busca de salvação, procura nos filhos a esperança de deixar semente de memória segura. Conclui, todavia, que nenhum deles garante a continuidade da casta, nenhum possui o perfil aristocrata legado pelos antepassados (p. 207).

A ironia do destino, que é talvez a inextrincável sabedoria da vida, recusa ao Príncipe o último desígnio de poder receber a fúnebre visita no conforto do seu lar, ou pelo menos, no seio de uma propriedade sua. É na impessoalidade do hotel que percebe finalmente que não fora mais do que um administrador dos bens terrenos, como avisa Bellarmino. Nada lhe restou de verdadeiramente seu, e quem nada tem, nada pode legar ${ }^{15}$. Foi inútil preocupar-se com a manutenção de bens inevitavelmente condenados a desaparecer, ou a ser transformados em outros géneros, por um Sedàra calculista. Nem sequer a ancestral tradição gentílica podia vencer as leis do esquecimento, uma vez que a sua autoridade já tinha caído nas mãos dos seguidores - e dos traidores - de Garibaldi que, apesar de tudo, triunfara sobre o Leopardo dançante. Sem poder decisório, sem sequer reconhecer o próprio rosto na máscara refletida no espelho, o protagonista vê-se despojado de tudo, até da identidade (p. 205). Humilhado por essa camuflagem obrigatória que torna todos iguais diante da morte, aceita com resignação a ideia de que já não vale a pena tratar do corpo e repudia o desvelo de quem se disponibiliza a lavar o moribundo. Ao Príncipe de Salina restava, enfim, a dignidade de não ser manuseado com um bebé dependente, sentindo-se reduzido a um ultrajante grau de submissão.

A água podia até lavar a ténue camada de fuligem, acumulada na viagem, mas não apagaria os pecados, nem a consciência de que os ciclos históricos se repetem até à exaustão. Ciente de que o homem nunca deixa de ser senão pó, embora tenha a pretensão de ser "o sal da terra", como afirmara um dia com vanglória diante de Chevalley (p. 154), o último leopardo analisa as suas memórias esparsas e percebe que elas perdem a sua centelha de perenidade à luz do tema barroco do memento homo. $\mathrm{O}$ aristocrata admite, então, a convencional presença do padre para cumprir o ritual da extrema-unção, como preconiza o guia espiritual de Bellarmino (1620, p. 259). O cardeal enfatiza o papel da confissão como condição de acesso à vida eterna e lembra que os agonizantes devem arrepender-se, não só dos pecados cometidos, mas também das omissões de caridade. No entanto, adverte o jesuíta, de nada vale uma contrição simulada, porque é impossível enganar a divina Providência (1620,p. 236).

Filipa Marisa Gonçalves Medeiros Araújo. A ILUSÃo DE BEM VIVER E A ARTE DE BEM MORRER 
Este ritual, perfilado à cabeceira do exânime cristão pelo Papa Paulo V, a partir de 1614, conferia poder sacramental e simbólico aos ministros da Igreja, uma vez que presidiam ao momento mais solene da vida humana, que ganhou especial encenação no cerimonial fúnebre, intencionalmente abolido no romance para não ensombrar o enfoque na cena do último suspiro. Note-se, contudo, que é Concetta a tomar a iniciativa de chamar o clérigo, perante a hesitação do pai, que aparentemente se submete ao exame de consciência, embora não verbalize as suas notas de culpa. Mesmo na iminência da partida inevitável, o Príncipe adota o silêncio como sinal de obstinada altivez, talvez porque a remissão implicaria a negação de todo o seu curriculum uitae (p. 208). Não deixa também de ser significativo o facto de ser o padre a ajoelhar-se diante do moribundo, como se lhe impingisse a comunhão e a oração extrema, dando cumprimento a um costume imposto pela Igreja para alívio dos mortais. O compêndio De arte bene moriendi apresenta o último sacramento como uma bênção decisiva para o duplo benefício de absolver o corpo, através da unção dos cinco órgãos sensoriais (1620, p. 262), e de resgatar a alma. Parece-nos, por isso, que a breuitas de Lampedusa na descrição deste episódio indicia o fraco significado que teria para o Príncipe, em particular, e talvez para os fiéis no geral, cientes de que uns minutos de desesperada compunção não podem salvar uma vida de perdição.

Ainda assim, a aproximação do sacrossanto viático causa certa impressão no patriarca de Salina. Guardando um respeitoso silêncio, ouve a campainha que teria feito ajoelhar os transeuntes, no breve percurso desde a paróquia da Piedade e sente a sua presença subir as escadas, passar o corredor, transpor a porta, provocando um incómodo sentimento nos outros hóspedes, também eles com um lugar certo na fila de espera. D. Fabrizio conhecia bem essa sensação e finalmente podia alegrar-se por ser o destinatário do cortejo, como desejava desde a noite do baile (p. 181). Nesse momento, a sua carruagem fora imobilizada pelo gracioso som da campainha, alegremente agitada pelo rapaz que anunciava a passagem do Santíssimo, cumprindo a missão de aplacar mais uma agonia. Ao invés do que sucedera na altura do encontro fortuito, o pai de Concetta sabe que não vai continuar o seu rumo depois de ver passar o Santíssimo e recebe finalmente o itinerante lenitivo. O efeito interior não traz, todavia, o consolo esperado. Talvez por isso a alma do Príncipe não tenha conseguido resistir a um último encantamento, mesmo depois de cumprido o ritual da confissão e da comunhão.

As tentações dos moribundos estão previstas nos capítulos IX a XI do manual de Bellarmino (1620, p. 264-284). O cardeal romano reserva-os para tratar das derradeiras provocações da heresia, que atenta contra a fé; do desespero, que compromete a confiança na ressurreição; e do ódio a Deus, que incita à revolta. $\mathrm{O}$ protagonista do romance parece afligido pelas três porque não demonstra uma 
autêntica crença na doutrina cristã, não acredita na salvação e não procura unir-se ao pai Celeste no seu amor infinito. Para D. Fabrizio, o trespasse teria de mostrar uma configuração mais sedutora, pelo que a aparição sob a forma de mulher em traje de passeio se adequa perfeitamente ao imaginário do voluptuoso Leopardo. Por outro lado, esta opção alegórica inscreve-se na longa tradição da Literatura cristã que designa a morte metafórica e eufemisticamente como uma viagem, transformando a alma numa errante peregrina em busca da sua meta ou num navegador que teme o naufrágio. Neste sentido, ganha particular relevo a raiz etimológica que denuncia a natureza caminhante do viaticum, 'aquele que percorre as vias' para acompanhar a fúnebre partida.

A Antiguidade entregou a Caronte a responsabilidade de conduzir as almas que abandonam o mundo terreno, mas esse não seria o condigno acompanhante de um príncipe galã. No romance, a morte adota uma imagem muito mais requintada, digna de prender o libidinoso olhar humano (p. 211). Na descrição feminina que surge inadvertidamente no meio do grupo de familiares, o leitor reconhece os traços comuns à mulher que o protagonista confessa ter admirado, no dia interior, na estação de Catania, com o mesmo vestido castanho, as mesmas luvas de camurça, o mesmo olhar atraente e misterioso. Assim se confunde realidade e delírio, sugerindo uma verosímil perda de lucidez no momento que antecede o trespasse, ao mesmo tempo que o narrador explora a pulsão erótica da cena. A jovem mulher, naturalmente conotada como indiscutível motivo de desejo, desperta o interesse visual do patriarca, que logo afasta o olhar da família chorosa para seguir aquela insinuante proposta, que pela segunda vez se cruza com ele e parece ter vindo propositadamente para o convidar a partir à aventura, num cenário que alude vagamente ao excitante desafio veiculado pelo mito do Expresso do Oriente. Apesar da diferença de idades, aquela viagem seria feita a dois, numa relação de intimidade que se adivinha pelo imediato levantar do véu. Com esta revelação, a mórbida figura feminina entrega-se, pronta a ser possuída pelo marido de Stella, o insaciável amante das estrelas que finalmente parece unir-se a um ser celeste (p. 211).

Importa frisar que a imagética sensual descrita no passamento de Fabrizio insinua uma atitude que vai ao encontro da mensagem de salvação difundida pelas artes moriendi, porque encara com otimismo o momento de libertação da alma, reconhecendo-lhe uma beleza fascinante. Isto não significa que o protagonista tivesse prevenido cristãmente a sua partida, mas revela uma certa analogia com uma encenação dialética típica da mentalidade barroca. In articulo mortis, o aristocrata repudia a vida e os princípios que regraram a sua existência e agarra-se à ilusão do vazio post mortem. Esta postura contraditória segue a tendência necrófila da literatura do século XVIII, com especial apetência por cenas tumulares e noivados sepulcrais, enriquecidos pelos episódios 
fantásticos de mortos-vivos (Aries, 1977, p. 29). Convém salientar que tal propensão casa paradoxalmente as duas grandes pulsões do homem - a libido e o instinto de sobrevivência -, dado que expressa a luta contra a natureza humana, na tentativa de controlar a sexualidade e superar a morte.

De acordo com o que tinha previsto diante do quadro de Greuze, o elegante par de Angélica encontrou a morte rodeado pela família chorosa, obedecendo a um comportamento mais decoroso e a uma postura menos lasciva. Contrastando, porém, com a brancura do moribundo retratado, a alma de Fabrizio estava pejada de nódoas, e de nada adiantou a intervenção do padre. Além disso, o patriarca de Salina parte com o desgosto de não expirar no seu leito, longe da fiel presença canina que enriquecia a pintura, e com a dolorosa certeza de não deixar uma descendência assegurada. A verificação destas diferenças, que não apontam meros pormenores, fundamenta a interpretação de que o lúgubre ambiente do hotel Trinacria não se identifica com a realidade pintada na Morte do Justo porque, afinal, o grande, orgulhoso e enraivecido Leopardo estava longe de ser um homem justo. Apesar de ter a clarividência suficiente para reconhecer os seus erros, nunca foi capaz de os admitir e falece sustentando a firme convicção de que mais valia aniquilar definitivamente a sua personalidade do que contorcer os seus princípios para os adaptar a uma nova realidade. Essa teimosia inflexível e anticristã condenou-o ao triste fim dos que se recusam a reaprender a viver, segundo os parâmetros da fé, como conclui o tratado De arte bene moriendi no capítulo XV. Esses infelizes, lembra Bellarmino (1620, p. 305), nem sequer têm a hipótese de desaparecer como os restantes animais desprovidos de alma, dado que, embora não acreditem, o seu espírito será submetido a um Juízo final e ao posterior castigo eterno.

Mas haveria pior sentença para o senhor de Salina do que saber antecipadamente que todas as suas propriedades seriam usurpadas? Que toda a sua estirpe seria extinta? A morte surge, assim, como uma estratégica fuga para o vazio, de modo a escapar à humilhação de ver toda a sua vida subsistir apenas numa pequena tela no quarto de Concetta. Aceitando o fim absoluto, o patriarca escapa à humilhante observação do destino familiar. A jovem em traje de passeio abre, portanto, as portas da evasão e poupa o Príncipe ao duro golpe de ver o prestígio da sua linhagem junto da Igreja ser destruído pelo exame às falsas relíquias. Em última instância, Fabrizio desaparece antes de assistir à derrocada geral da sua casa e da sua classe, simbolizada na queda de Bendicò. Também este ícone da família Salina foi reduzido a um monte de pó, atirado pela janela para a sua sepultura eterna. O Príncipe que viveu dominado pela ilusão de tudo possuir na Terra, morreu com a certeza de ter finalmente atingido o Nada. O seu processo de corteggiamento della morte, embora siga formalmente os parâmetros das convencionais artes de bem morrer, dissimula um percurso interior 
muito distinto do previsto, uma vez que envereda por um caminho irreversível até ao vazio do espaço sideral.

\section{O NADA QUE É TUDO}

Enquanto o manual De arte bene moriendi transmite aos mortais uma mensagem de esperança que os ensina a confiar no bom sucesso do caminho para a vida eterna, o romance de Lampedusa, pelo contrário, veicula aos leitores uma imagem de desencanto que os leva a desconfiar do sentido da vida, pois esta que conduz inevitavelmente ao aniquilamento definitivo. No entanto, as duas obras apontam para um ambiente de pacificação cósmica, a primeira através da elevação ascética, a segunda através do vazio desconhecido.

Importa, pois, destacar que ambas foram construídas a partir de alicerces fundados numa dialética de opostos, que constitui, como já foi referido, o cerne da mentalidade barroca claramente expressa no manual do século XVII, e subentendida no romance histórico da mundividência siciliana. O cardeal Montepulciano desenvolve toda a sua erudita argumentação, copiosamente documentada pela autoridade dos textos sagrados, com base no contraste entre vida terrena e existência divina, recompensa celeste e castigo infernal. O duque de Lampedusa, por seu lado, explora a oposição entre aparência e essência, vida mundana e morte sublimada, marcando a distinção entre a plenitude e o vazio.

$\mathrm{Na}$ verdade, o quarto do Hotel Trinacria, um espaço estranho e impessoal, coloca o marido de Stella numa espécie de limbo, onde é confrontado com uma antevisão do abandono e do esquecimento a que será votado, sem que o narrador precise de recorrer a imagens de horror. Pelo contrário, o discurso comprova com magistral suavidade a supremacia expressiva das metáforas naturais, explorando a simbologia inesgotável da água para plasmar a polifonia interior do protagonista. O barulho das ondas reflete o vigor da natureza, por oposição ao desfalecimento do moribundo, ao mesmo tempo que lembra a irreversibilidade do tempo. Com efeito, o autor de $I l$ Gattopardo compôs um quadro de símbolos nictomórficos extraordinariamente eloquente para exprimir a incerteza que assombrava o protagonista, consciente de que a sua existência iria obliterarse nas trevas do esquecimento. Esta diluição do indivíduo foi, de resto, assinalada por Rita Marnoto (1985, p. 88), que a integra num processo global de destruição. Isto não significa, porém, que Lampedusa pretendesse refletir sobre a morte numa perspetiva niilista. Adota, na verdade, uma 
postura intrinsecamente problematizante pelo seu carácter dualista, fazendo lembrar o diálogo criado por Schopenhauer e dramatizado por Trasímaco e Filaletes. Pretende-se, acima de tudo, questionar se a existência de um indivíduo pode ou não ser destruída pela aniquilação física e este é um dos aspetos mais prementes da angústia vivida pelo rebuscado homem barroco, recuperada, em tempos mais recentes, pelo existencialismo filosófico.

Muito se tem escrito sobre a tese que interpreta o perfil do felino protagonista como um espelho distorcido do autor, numa tentativa de "autobiografia às avessas" (ORLANDO, 1998, p. 13). Outros sustentam uma leitura que pressupõe uma identificação mais imediata, tendo em conta a ascendência aristocrata de ambos e a dolorosa vivência de uma época de crise (BASSANI, 2005, p. 11). O Príncipe de Salina assistiu à queda do mundo borbónico aos pés de Garibaldi, submetendo a Sicília à integração forçada no processo de Unificação italiana. O duque de Lampedusa testemunhou a derrota do fascismo às mãos dos Aliados, o que deu origem a uma longa fase de reconstrução no período pós-guerra, de modo a recuperar da mutilação social. Daí que a tonalidade decadentista e pessimista do best-seller publicado em 1958 se adaptasse perfeitamente à perceção histórica vigente, predominantemente negativa e degenerativa, que encontrava eco no lema de Tancredi: “É preciso que tudo mude, para que tudo fique na mesma". O discurso de Il Gattopardo privilegia, no entanto, uma linguagem poética de profunda ambivalência metafórica e não necessariamente negativa. Notese que a morte-libertadora de D. Fabrizio surge como prenúncio de uma viagem até à mais bela estrela, concretizando, por fim, a grande aspiração da sua vida. É certo que a queda vertiginosa de Bendicò enfatiza o sentimento destrutivo predominante, mas sente-se, no texto, um contínuo oscilar entre pólos antagónicos que dita a perenidade da proposta de reflexão "sulla grande poesia della morte in cui consiste la ragione profonda della sua eccezionalità" (SQUAROTTI, 1961, p. 283).

Com efeito, pensar a vida e problematizar a morte são questões ancestrais a que o homem continuamente procura dar resposta, de acordo com as coordenadas culturais e espácio-temporais que delimitam o seu horizonte de expectativa. No mundo atual não há tempo para preparar a morte, pelo que o moribundo perdeu o consolo de se despedir da vida no seu leito doméstico, sob o olhar carinhoso da família. O homem moderno foge da imagem de finitude, desumaniza-a, anestesia-a com medicamentos, ludibria-a com operações de estética, dissuade-a com atividades frenéticas, prende-a nos hospitais, disfarça-a com funerais rápidos e discretos, a que se segue um luto desanuviado, porque " A morte deve apenas tornar-se a saída discreta, mas digna, de um vivo apaziguado, fora de uma sociedade compassiva que a ideia de uma passagem biológica, sem significado, sem dor nem sofrimento, já não despedaça nem perturba, e finalmente, sem angústia” (ARIES, 1977, p. 373). 
Procurando dar resposta às angústias do espírito barroco, o manual de Bellarmino faz eco das Sagradas palavras e traça um percurso que promete conduzir o homem à tranquilidade da recompensa divina, em troca de um grande esforço de desprendimento, de renúncia, de humilhação. Refletindo as preocupações contemporâneas, o romance de Lampedusa recorre à história de D. Fabrizio para espelhar a incerteza humana perante a vida e inerente incapacidade de lidar com as limitações da sua condição precária. A arte de bem morrer lembra que é preciso não desejar nada, para receber, nas mãos vazias e puras, tudo o que Deus pode oferecer. O romance prova, através da mórbida atitude do Príncipe, que só a negação de qualquer expectativa pode conduzir à libertação. As duas obras prefiguram, pois, cada qual ao seu estilo, uma lição de bem viver num mundo de contrastes onde os opostos se atraem. Bellarmino optou pelo discurso assertivo, Lampedusa preferiu o hipotético. O primeiro escolta-se da autoridade da Igreja, o outro inspira-se na sociedade e na história. No entanto, ambos partilham uma visão dialética da existência, entendida como um breve percurso entre o nascimento e o ocaso, entre o ser e o parecer, entre a consciência de nada ter e a ambição de tudo possuir. A vida é nada, mas é tudo o que temos. A morte também é nada, mas é tudo o que sabemos. E que será o homem, afinal, senão um "nada" que é "tudo"?

\section{THE ILLUSION OF LIVING WELL AND THE ART OF DYING WELL WITHIN LAMPEDUSA'S IL GATTOPARDO}

ABSTRACT: The interpretation of Lampedusa's masterwork usually focuses on the spatial and chronological references associated to the author or the characters. Nevertheless, the complex literary weaving of the historical romance allows the establishment of intertextual links beyond that strict referential sphere. Taking into account the structural significance of the corteggiamento della morte, we can identify underneath the narrative some vestiges of the mental schemes typically connected to barroque dialectics. The presence of this motive is not only a thematic isotopy, but also a determining factor to the protagonist's characterization and to the narrative conception itself. Consequently, we propose an analysis to Il Gattopardo in the light of the principles drawn by the Artes moriendi of the seventeenth century. The comparison with Bellarmino's ascetic manual shows the similarities between two texts so distant, concerning time and gender, but so close, regarding the thanatological perspective that both reflect. 
KEYWORDS: Historical romance; Death, Ars moriendi.

\section{NOTAS}

1 O responsável pela edição enaltece, nestes termos, os aspetos mais carismáticos da obra: «Ampiezza di visione storica unita a un'acutissima percezione della realtà sociale e politica dell'Italia contemporanea, dell' Italia di adesso; delizioso senso dell'umorismo; autentica forza lirica, perfetta sempre, a tratti incantevole, realizzazione expressiva: tutto ciò, a mio aviso, fa di questo romanzo un' opera d' eccezione. Una di quelle opere, appunto, a cui si lavora o ci si prepara per tuta una vita.» (BASSANI, 2005, p. 10).

${ }^{2}$ Sobre o tema da morte no romance, veja-se Samonà (1974, p. 167-191) e Salvestroni (1973, p. 47 54).

${ }^{3}$ Para um desenvolvimento desta questão, no contexto italiano, aconselha-se os estudos de Baldi (2002) e de Magliozzi (2005).

4 As Artes moriendi integram o corpus da Literatura Cristã, na medida em que servem de guia prático para a prossecução de um caminho de acesso direto à vida eterna. Estes antepassados do catecismo preparavam o homem para o encontro com a morte, mediante a concretização de boas ações e a prática da oração, de forma a purificar a alma. Sobre a profícua evolução deste género, que apareceu nos finais da Idade Média e manteve a sua influência até ao século XVIII, pelo menos de forma mais visível, consulte-se Duclow (2003), O’ Brien (2001) e O' Connor (1966). Erasmo de Roterdão, reconhecido pela sua visão humanista da religião cristã, compôs o tratado $D e$ praeparatione ad mortem cum Epistolis aliquot (Antuérpia, Mich. Hillen van Hoochstraten, 1534), em que simula um diálogo entre o Diabo e o moribundo, de modo a lançar um apelo dramático para a necessidade de preparar a morte através de uma vida regrada.

${ }^{5}$ O cardeal Bellarmino (1542-1621), natural de Montepulciano, entrou para a Companhia de Jesus aos dezoito anos, tendo estudado Filosofia no Colégio de Roma. A obra De Controuersiis garantiulhe a notabilidade a nível europeu e o reconhecimento junto da Santa Sé, tendo redigido o prefácio da Vulgata. Tornou-se reitor do Colégio de Roma em 1592 e, mais tarde, Clemente VIII nomeou-o seu Teólogo e Consultor do Santo Ofício, antes de o consagrar Arcebispo de Cápua. Na fase final da sua vida, Bellarmino regressou à Cidade Eterna, assumindo funções no Tribunal do Santo Ofício, que julgava, então, o processo de Galileu (DONNELLY e TESKE, 1989, pp. 11-20). 
${ }^{6}$ Viuere tota uita discendum est et, quod magis fortasse miraberis, tota uita discendum est mori, Séneca, De brevitate vitae, VII, 3-4.

7 'Noblemen are trained to regard nothing more sacred than their word of honor, to believe earnestly, rigidly, an firmly in the inane code of knight-errantry, and if necessary to seal their belief by death, and to look upon a king as a being of a higher order" (SCHOPENHAUER, 2004, p. 120).

${ }^{8}$ Logo no primeiro capítulo, o narrador sugere essa aniquilação quando os monogramas do Príncipe impressos no copo com que brinda à saúde do sobrinho deixam de ser visíveis, imediatamente depois de o esvaziar, num sinal premonitória de discreta expressividade (p. 43).

9 'Era un giardino per cechi: la vista costantemente era offesa: ma 1' odorato poteva trarre da esso un piacere forte, benchè non delicato" (p. 18).

${ }^{10}$ No século XIV, predomina a imagética do Juízo final, com Cristo a pesar as almas, num tribunal onde não faltam os símbolos judiciais - a balança de S. Miguel, o gládio do Arcanjo Gabriel, e o livro da vida -, bem como a presença intercessora da Vigem Maria. Na centúria seguinte, assomam novas formas iconográficas, sobretudo gravuras de madeira, construídas para auxiliar a meditação doméstica, de acordo com algumas referências disseminadas pelas artes moriendi. Além disso, os livros de emblemas religiosos, como os Pia desideria (1624) de H. Hugo, reconstituem cenas com o moribundo no centro de um quarto adornado com o crucifixo à cabeceira da cama, acrescentando, por vezes, os familiares lacrimosos, o padre em oração, o anjo que recebe a alma e os demónios que espreitam a oportunidade de desencaminhar o sopro vital. Este registo afasta-se claramente das representações mais aterradoras que procuravam manter diante dos olhos a representação da caveira e do crucifixo. A linguagem verbal dos compêndios foi roubando espaço às imagens doutrinais, que pretendiam apavorar os fiéis com a perseguição da mors improvisa, conduzindo uma carroça onde acumulava os corpos (ARIES, 1977, p. 135).

${ }^{11}$ Não será mera coincidência a identificação do nome do hotel com um dos reinos da Sicília, votado ao esquecimento dos séculos, como parecia ser o destino do Príncipe de Salina.

12 Ironicamente, também Lampedusa morreu longe da sua terra natal, em Roma, aonde se tinha deslocado para uma última tentativa de cura.

13 Orlando (1998, p. 81-82) sublinhou a originalidade desta despedida da vida: "Affidando formalmente la specificità di questa morte a un commovente monologo interiore, più rigoroso che dovunque altrove nel suo romanzo, Lampedusa ha dotato d'una novità senza modelli la letteratura occidentale del Novecento". 
${ }^{14}$ Bellarmino (1620, p. 212-220) considera três aspetos fundamentais: lugar, tempo e modo do castigo infernal. No que diz respeito ao primeiro, o cardeal situa a nefanda morada nas profundezas da Terra, onde não penetra a luz das estrelas, acrescentando que as sentenças ditadas por Deus duram por toda a Eternidade. O método de aplicação da punição mostra-se igualmente inflexível e contínuo, tendo em conta que, numa situação de carência extrema, a única forma de riqueza se manifesta na quantidade dos terríveis suplícios.

15 ARIÈs (1977, p. 60-63), refletiu sobre a influência da "tentação do nada" na Literatura.

\section{REFERÊNCIAS}

ARAúso, Ana Cristina. A morte em Lisboa. Lisboa: Editorial Notícias, 1997.

ARIES, Philippe. O Homem perante a Morte. Mem Martins: Europa-América, 1977.

BALDI, Giusso et al. Dalla Scapigliatura al Postmoderno, dal testo alla storia, dalla storia al testo. Milano: Paravia, 2002.

BASSANI, Giorgio (ed.). Il Gattopardo. Milano: Feltrinelli Editore, 2005.

Bellarmino, Robertus. De arte bene moriendi libri duo. Lugduni: Sumptibus Iacobi Cardon et Petri Cavelat, 1620 .

Bellarmino, Robert. The art of Dying well, Transl. by Rev. John Dalton. London: Richardson and Son, 1847.

Donnelly, John Patrick e Teske, Roland (ed.). Spiritual Writings of Bellarmine. New York: Paulist Press, 1989.

DuClOw, Donald F. Ars Moriendi. Macmillan Encyclopedia of Death and Dying. The Gale Group Inc, 2003.

Maeterlinck, Maurício. A Morte, tradução de Cândido Figueiredo. Lisboa: Clássica, 1917. (reedição com prefácio de José Zaina. Alpiarça: Garrido Artes Gráficas, 1997).

MagliozzI, et al. Il Decadentismo in Spazi e testi letterati. Napoli: Ferraro Editori, 2005.

MARNOTO, Rita. La fine di tutto: Um «fim» completo. Estudos Italianos em Portugal, n. 48-49-50, 1985-86-87.

NIGRO, SS. Il romanzo di un turista. TOMASI, Lanza e NIGRO, S. (Eds.) Lampedusa. Viaggio in Europa. Epistolario 1925-1930. Milano: Mondadori, 2006, p. 5-40.

O'BRIEN, Mary Ellen. Living well \& dying well: a sacramental view of life and death. Lanham: Rowman \& Littlefield, 2001. 
O' Connor, Mary Catherine. The Art of Dying Well: The Development of the Ars Moriendi. New York: AMS Press, 1966.

ORlando, F. L'intimità e la storia. Lettura del “Gattopardo”. Torino: Einaudi, 1998.

Rocha Pereira, Maria Helena. Hélade, Antologia de Cultura Grega. Coimbra: Imprensa de Coimbra, 1998.

Russo, Luigi. Analisi del Gattopardo. Belfagor, XV, n. 5, p. 513-530, set. 1960.

SAlVeStRoni, Simonetta. Tomasi di Lampedusa. Firenze: La Nuova Italia, 1973.

SAMONÀ, Giuseppe. Il Gattopardo, I Racconti, Lampedusa. Firenze: La Nuova Italia, 1974.

SCHOPEnHAueR, Arthur. Essais of Schopenhauer. Trad. Rudolf Dircks. Kessinger Publishing, 2004.

SQUAROTTI, Giorgio. Poesia e Narrativa del secondo novecento. Milano: Mursia, 1961. 